\title{
Standarizing in planta Agrobacterium tumefacience mediated genetic transformation protocol to develop new events by transforming $G$. hirsutum cotton based on Cry1Ac-Cry1Ec genes
}

\author{
Yanal A. Alkuddsi", Shreekanth S. Patil, S. M. Manjula, K. J. Pranesh, B. C. Patil \\ Agricultural Research Station, University of Agricultural Sciences, Dharwad- 580005, Karnataka, India
}

Email address:

y.alkuddsi@hotmail.com (Y. A. Alkuddsi)

\section{To cite this article:}

Yanal A. Alkuddsi, Shreekanth S. Patil, S. M. Manjula, K. J. Pranesh, B. C. Patil. Standarizing in Planta Agrobacterium Tumefacience Mediated Genetic Transformation Protocol to Develop New Events by Transforming G. Hirsutum Cotton based on CrylAc-CrylEc Genes. American Journal of Life Sciences. Vol. 2, No. 4, 2014, pp. 190-199. doi: 10.11648/j.ajls.20140204.11

\begin{abstract}
Cotton breeding for insect resistance has been limited by a lack of sufficient genetic variation in the existing germplasms. Therefore, genetic engineering provides the possibility of creating varieties carrying new properties coming even from heterologous source. Exogenous pesticidal transgenes can be introduced into plants. Agrobacterium mediated plant transformation offers advantages like reducing copy number of the transgene and little co-suppression. Inter specific hybrids are known to be more susceptible to biotic stress. It is hence important to develop $B t$ version for inter specific hybrid. Presently, the $B t$ gene commercialized are owned by private sector. It is necessary to develop public sector's $B t$ event and commercialize them. UAS Dharwad is involved in developing public sector $B t$ cotton genotypes. One variety, RCR4 (Gossypium hirsutum, L.) was used in the present investigation. CrylAc-CrylEc genes are to control Helicoverpa armigera and Spodoptera litura. The seedlings in pots were co-cultivated with solid Agrobacterium culture after cutting the meristematic tip with sharp knife. The number of seedlings co-cultivated, number of seedlings established and the number of seedlings showing transformed status are presented in this study. PCR was performed to confirm the presence of the transgene in the plants that were selected to be advanced further. The results showed that non of plants had trangenes CrylAc-CrylEc as detected through PCR amplification. In planta genetic transformation was carried out and the plants were tested in $\mathrm{T}_{0}$ generation by means of PCR amplification for the genes CrylAc-CrylEc. The results obtained were not amplified the CrylAc-CrylEc. Hence the transformation of the genes was not up to mark and the plants of $\mathrm{T}_{1}$ generation are also not confirmed.
\end{abstract}

Keywords: Genetic Transformation, Agrobacterium Tumefacience, G. Hirsutum, Cry1Ac-Cry1Ec Genes

\section{Introduction}

Recent advances in plant molecular biology techniques have given birth to unprecedented opportunities for the introduction of novel traits into crops. The potential impact of these powerful methodologies on the genetic improvement of crop plants of economic importance has generated considerable interest, enthusiasm and optimism in the scientific community and is in part responsible for the rapid expansion of biotechnology industry. The anticipated role of plant biotechnology in agriculture is attributable to the production of genetically superior plants as well as elegant demonstrations in model experimental systems that new hybrids, mutants and genetically engineered plants can be obtained by these methods. The world wide pre-harvest losses due to insect pests despite the use of insecticides are $15 \%$ of total production representing over US\$ 100 billion (Krattiger and Anatole, 1997).

Genetic transformation requires penetration of the transgene through the plant cell wall, facilitated by biological or physical methods (Electroporation, Biolistics, Vacuum infiltration, Ultrasound-mediated transformation, Shock wave-mediated transformation, Silicon carbide whisker-mediated transformation, Microinjection, Macroinjection, Lasermicrobeams and Electrophoresis). There are various methods available to breed genetic 
resistance against insects and pests, these include conventional breeding and transgenic technology. Exogenous pesticidal transgenes can be introduced into plants by Agrobacterium mediated transformation. Agrobacterium mediated transformation offers advantages like reducing copy number of the transgene, little co suppression (Konez et al., 1994; Hansen et al., 1997, Enriquez Obregon et al., 1998). However, Agrobacterium tumefaciens infects naturally only dicotyledonous plants and also many economically important plants including the cereals are also made to infect with difficulty.

Bacillus thuringiensis is a gram positive, rod shaped spore forming soil bacterium. It produces the crystal insecticidal proteins during sporulation called delta endotoxins. These crystal proteins are toxic to larvae of different insects. e.g, Lepidopterans (Krieg et al., 1983; Herrnstadt et al., 1986) and dipteran insects, causing eventual death of the larvae (Hoftey and Whiteley 1989; Aslam et al., 2000). Many different crystal protein genes called Cry genes have been isolated and classified on the basis of amino acid sequence homologies. At least 90 genes encoding protoxin from a wide range of $B t$ isolates have been isolated and sequenced (Maizer et al., 1997).

Technology for gene delivery plays an important role in the process of plant genetic engineering. Foreign genes are introduced into genome of recipient species either by physical, chemical or biological means. Since the first transgenic plant appeared in 1983, studies on plant transformation techniques have achieved a great progress.

Plant transformation mediated by the soil plant pathogen Agrobacterium tumefaciens is simple method for plant transformation. There are two tumorgenic species i.e. Agrobacterium tumefaciens and Agrobacterium rhizogene. Agrobacterium tumefaciens is a gram negative soil bacterium, causes crown gall tumors (neoplastic disease) on many dicotyledonous and some monocotyledonous plants (Broer et al., 1995). During plant infection A. tumefaciens, transformed plants by transferring a part of its DNA called transferred DNA (T-DNA) from its tumour inducing (Ti) plasmid to the plant genome. The virulence (Vir) region of the $\mathrm{Ti}$ plasmid codes for the function required for processing and transfer of T-DNA (Lyer et al., 1982; Stachel and Nester, 1986). The discoveries that T-DNA codes for oncogene which is only transferred to plant cell genome (Bevan et al., 1983a) and non virulent or disarmed strains i.e. containing T-DNA from which oncogenes have been removed and replaced by any other gene of interest, behave in the same way as virulent strain do, that opened a new avenue in transformation of interested gene to higher plants (Fig. 1).

Katageri et al. (2007) reported development of transgenic cotton using shoot apical meristems, which was isolated from seedlings as explant. Synthetic gene encoding Cry $1 A c$ endotoxin of Bacillus thuringiensis was used for transformation. Regeneration of shoots was carried out in selection medium containing kanamycin $(100 \mathrm{mg} / \mathrm{l})$ after co-cultivation of the explants with Agrobacterium tumefaciens. Progeny obtained by selfing $\mathrm{T}_{0}$ plants was grown in the greenhouse and screened for the presence of neomycin phosphotransferase (nptII) and CrylAc genes by polymerase chain reaction (PCR) and Southern hybridization. Expression of $C r y l A c$ in the leaves of the transgenic plants was detected by strips and quantified by Quan-T ELISA kits. Insect bioassays were performed with the larvae of cotton bollworm (Helicoverpa armigera). Results of the field tests showed considerable potential of the transgenic cotton for resistance against cotton bollworm.

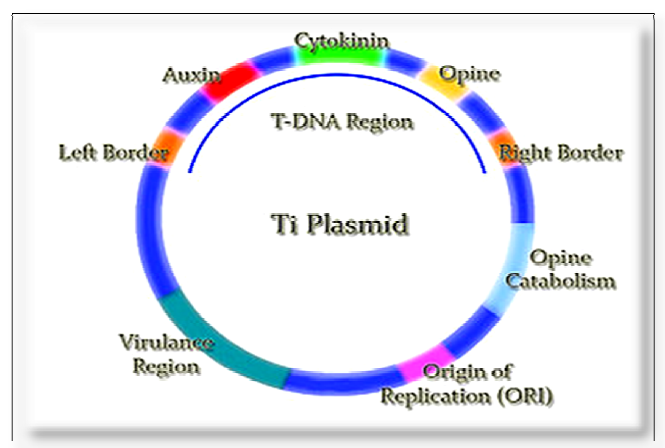

Fig. 1. Ti Plasmid Construction in Agrobacterium tumefaciens

The main objective of this study is: Standarizing in planta Agrobacterium tumefacience mediated genetic transformation protocol to develop new events by transforming G. hirsutum cotton based on CrylAc-CrylEc genes.

\section{Materials and Methods}

In this study, genotype independent in planta transformation of cotton ( $G$. hirsutum) variety RCR4, using injection method and cut method has been reported. Agrobacterium tumefaciens strain carrying the nptII and CrylAc-CrylEc genes was used for plant transformation. The integration of the genes was confirmed by using PCR ( $\mathrm{T}_{0}$ generation).

The present investigations were carried out at Agricultural Research Station, Dharwad farm, University of Agricultural Sciences, Dharwad during 2012.

\subsection{Materials}

\subsubsection{Genotype}

One variety, RCR4 (Gossypium hirsutum, L.) was used in the present investigation.

- This line is productive line with high Relative Growth Rate (RGR).

- Developed by Dr. S.S.Patil, Senior cotton breeder, Agricultural Research Station, Dharwad farm, University of Agricultural Sciences.

- It is known to be productive in rainfed situation.

- $\quad$ The parentage of this line RAH 100 X RAH 101.

\subsubsection{Cry Genes}

The genes used for transformation was obtained from 
NBRI Luknow and it was spared by Dr. P.K.Singh under NMITLI project funded by Counsil of Scientific and Industrial Research New Delhi, India.

\subsection{Methodology}

\subsubsection{Preparation of Explants}

- Delint the genotype seeds by using sulfuric acid $\left(\mathrm{H}_{2} \mathrm{SO}_{4}\right)$ were dipped for 10 minutes with constant stirring followed by the repeated washes with water. Keep the seeds under the sunshine to dry completely.

- Delinted and surface sterilized seeds soaked in sterile water over night were used to establish the plants for transformation.

\subsubsection{Sowing and Establishment of Plants}

The seeds were sown on 1-1-2012 in 200 plastic packets containing sterilized black soil mixed with Bavistin (5 g/1L), 2 seeds were dibbled per packet and thinning was attended to retain one healthy plant per plastic packet at 25 days after sowing. All the recommended package of practices were followed to rise healthy crop.

\subsubsection{Agrobacterium Strain and Binary Vectors}

The disarmed Agrobacterium strain LBA 4402 harbouring binary vector pCAMBIA, carrying CrylAc$C r y 1 E c$ genes linked to the CaMV35S promoter, the nos transcription terminator (amplified from $\mathrm{Pb} 101.1$ with $M f e I$ and EcoRI restriction sites at the ends) and $n p t$-II gene under the control of nopaline synthase (nos) promoter and terminator was used in transformation studies. Hygromycin resistance as selection marker and CrylAc-CrylEc genes are used to control Helicoverpa armigera and Spodoptera litura.

\subsubsection{Maintenance of Agrobacterium}

The Agrobacterium LBA 4402 containing above mentioned genes was maintained on solid Yeast Extract Mannitol Agar (YEM) medium containing kanamycin at 50 $\mathrm{mg} / \mathrm{ml}$ and $25 \mathrm{mg} / \mathrm{ml}$ rifampicin. It was subcultured once in every 30-40 days on fresh medium and incubated at $28{ }^{\circ} \mathrm{C}$ temperature for 48 hours followed by $4-6{ }^{0} \mathrm{C}$ for rest of the period.

\subsubsection{Preparation of Agrobacterium Culture for Co- Cultivation}

\subsubsection{Liquid Culture}

A colony of bacteria grown for 48 hours was taken from petridish and was inoculated in $150 \mathrm{ml}$ of liquid YEM medium containing $50 \mathrm{mg} / \mathrm{l}$ of Kanamycin and $25 \mathrm{mg} / \mathrm{l}$ rifampicin and incubated for $45-48$ hours at $22{ }^{0} \mathrm{C}$ under orbital shaker with $150 \mathrm{rpm}$. When bacterium growth reached to OD $(600 \mathrm{~nm})$ of $0.6 \mathrm{~g}$ pellet of bacterium obtained after centrifuge at $8000 \mathrm{rpm}$ for 5 minute. It was resuspended in $150 \mathrm{ml}$ of MS medium and $150 \mu \mathrm{M}$ of acetosyringone was added to the Agrobacterium culture before 30 minute of its use.

\subsubsection{Solid Culture}

A load of bacteria from a stock plate was taken from petridish to streak on a fresh petridish having solid YEMA medium with $50 \mathrm{mg} / \mathrm{l}$ of Kanamycin and $25 \mathrm{mg} / \mathrm{l}$ refampicin. The dish was incubated at $22{ }^{\circ} \mathrm{C}$ for 48 hours in dark. The bacteria were carefully collected after 48 hours into a $2 \mathrm{ml}$ new autoclaved eppendorf tube and $100 \mu \mathrm{M}$ Acetosyringone was mixed before 30 minute of its use by vortexing for few seconds.

\subsubsection{Transfer the Genes to the Plant tissue and Establishment in the Greenhouse}

1. The seedling shoot is embedded in the stem between the cotyledons, break off one cotyledons to expose shoot apex and cut the tissue in the shoot apex to make wound (Fig. 2).

2. The disarmed Agrobacterium strain LBA 4402 harbouring binary vector pCAMBIA, carrying CrylAc-CrylEc genes linked to the CaMV35S promoter, nos terminator and $n p t$ II gene transfer to the injuried tissue on $01 / 2 / 2012$ by using micropeppite (Plate 1).

3. Seedlings covered with plastic bags to maintain high humidity (Plate 1).

4. They were watered twice a week. Seedlings were then transferred to earthen pots on 5/3/2012 containing soil and vermicompost in equal proposition and pots were placed in transgenic green house for flowering.

\subsubsection{Screening Through PCR}

The putative transformants generated through in vivo genetic transformation were subjected to PCR analysis.

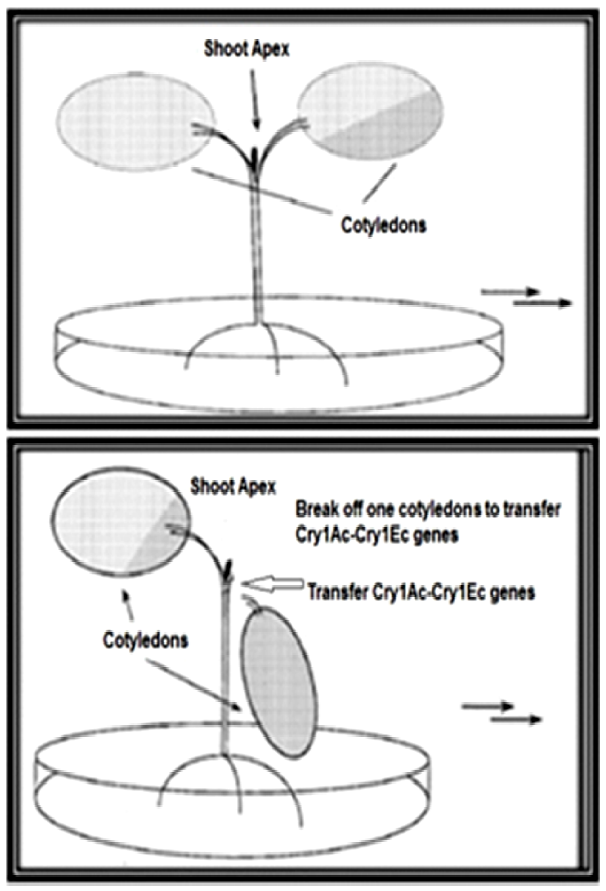

Fig. 2. Transfer the genes (CrylAc-CrylEc) to the plant tissue and establishment in the greenhouse 


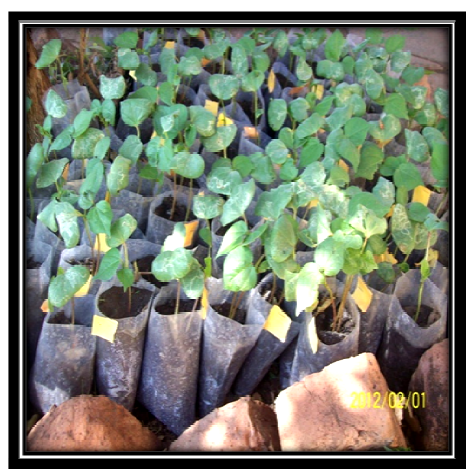

A

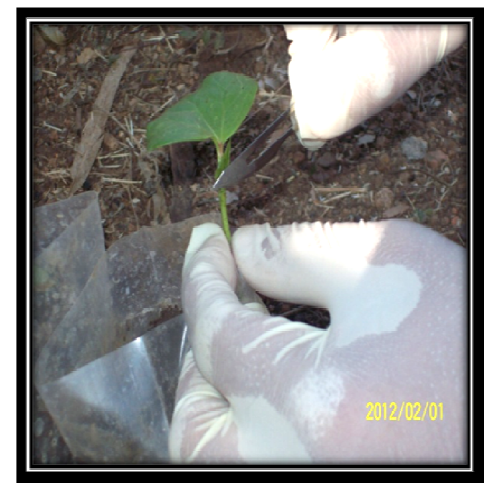

B

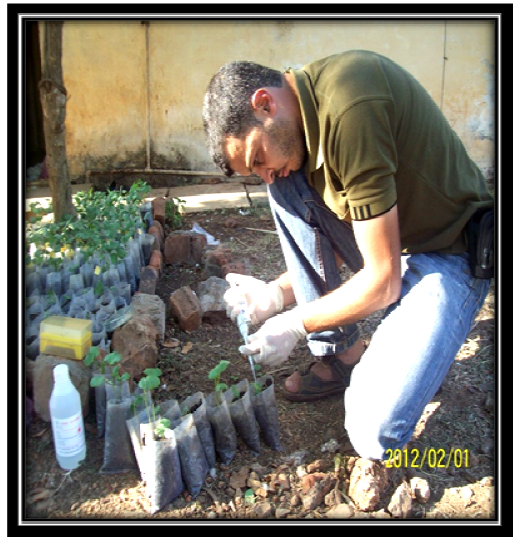

$\mathrm{C}$

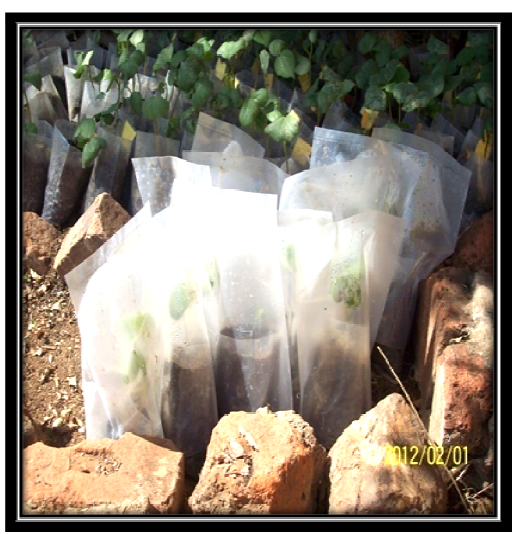

$\mathrm{D}$

Plate 1. Transfer the genes (CrylAc-CrylEc) to the plant tissue and establishment in the greenhouse

\subsubsection{DNA Extraction}

DNA extraction was done with CTAB method with few modifications.

1. One gram of fresh 2 nd or 3rd top most leaf was taken for DNA extraction, leaf was harvested and kept in the $1.50 \mathrm{ml}$ eppendorf tube.

2. By using extraction buffer leaf samples were crushed and kept in water bath for 45 minute at $65{ }^{\circ} \mathrm{C}$.

3. After $45 \mathrm{~min}$, samples were taken out from water bath. The solution was centrifuged at $8,000 \mathrm{rpm}$ for 10 minutes and supernatant was transferred to fresh eppendorf tube.

4. Supernatant was mixed with $500 \mu$ l of phenol: chloroform solution and centrifuged at 8,000 rpm for $10 \mathrm{~min}$.

5. By using micropipette, supernatant was collected and transferred to new eppendorf tube. To that eppendorf tube, $500 \mu \mathrm{l}$ chloroform solution was added and centrifuged at $8,000 \mathrm{rpm}$ for $10 \mathrm{~min}$.

6. Once again supernatant was collected to new eppendorf tube and $800 \mu$ isopropanol was added and kept at $20{ }^{\circ} \mathrm{C}$ for precipitation for 1-2 hours.

7. After 2 hours, tubes were removed from the deep freezer and kept out side to attain room temperature. After that, centrifuged at 5,000 rpm for $5 \mathrm{~min}$.

8. Supernatant was decanted without disturbing the pellet. To that, $70 \%$ alcohol was added and centrifuged for $5,000 \mathrm{rpm}$ for $5 \mathrm{~min}$. After centrifuge alcohol was decanted without disturbing the pellet.

9. Pellet was dried and suspended in $100 \mu \mathrm{l}$ of $1 \mathrm{X}$ $\mathrm{T}_{10} \mathrm{E}_{1}$ buffer.

10. $100 \mu \mathrm{l}$ RNase was added $(1 \mathrm{mg} / \mathrm{ml})$ to the DNA and incubated at $37{ }^{\circ} \mathrm{C}$ in water bath for half an hour.

11. DNA was precipitated using $1 / 10^{\text {th }}$ volume of $3 \mathrm{M}$ sodium acetate and ethanol and incubated over night at $4{ }^{\circ} \mathrm{C}$.

12. The solution was centrifuged at $13,000 \mathrm{rpm}$ for 2 min and pellet was dried again.

13. Pellet was suspended in $50 \mu 11 \mathrm{X} \mathrm{T}_{10} \mathrm{E}_{1}$ buffer.

\subsubsection{Estimation of Quality and Quantity of DNA}

The concentration and quality of DNA was assessed spectrophotometrically. It was also assessed with $0.8 \%$ agarose gel.

In spectrophotometric analysis, $5 \mu$ l of DNA sample diluted with TE buffer and volume made upto $3000 \mu \mathrm{l}$ was subjected to spectrophotometer reading at absorbance of $230 \mathrm{~nm}, 260 \mathrm{~nm}$ and $280 \mathrm{~nm}$. A good DNA preparation generally exhibits the following spectral property: A260/A280 > 1.80 DNA concentration was calculated using following formula. Concentration of DNA $(\mu \mathrm{g} / \mathrm{ml})=$ O.D. at $260 \times 50$. To test the quality and quantity of DNA, samples were run on 0.80 per cent agarose in $1 \mathrm{x}$ TAE (Tris Acetic acid EDTA) buffer and stained with ethidium bromide and checked for contamination by RNA and the DNA was evaluated by comparing it with a standard 
undigested DNA sample.

\subsubsection{Plasmid Isolation Procedure}

1. Inoculate $10 \mathrm{ml}$ media with suitable antibiotic and inculate with shaking at $3{ }^{\circ} \mathrm{C}$ overnight.

2. Take $1.5 \mathrm{ml}$ of culture in fresh tube and pellet at 13,000 rpm for 1 minute.

3. Discard the supernatant and take again $1.5 \mathrm{ml}$ of culture in fresh tube and pellet at 13,000 rpm for 1 minute.

4. Resuspend the pellet in $150 \mu$ l of ice cold solution I by vortexing.

5. Add $250 \mu \mathrm{l}$ of freshly prepared solution II and mix by inventing for 5 times and keep in ice for 5 minutes (don't vortex).

6. Add $200 \mu \mathrm{l}$ of solution III, mix by vortexing and keep in ice for 4-5 minutes.

7. Spin at max speed $(13,000 \mathrm{rpm})$ for 10 minutes at 4 ${ }^{0} \mathrm{C}$.

8. Transfer supernatant to fresh tube and equal volume of chloroform: Isomyl Alcohol (24:1) and mix by vortexing.

9. Centrifuge at max speed at $4{ }^{0} \mathrm{C}$ for 10 minutes.

10. Transfer aqueous phase to fresh tube.

11. Add 2 volume of pre chilled absolute isopropanol and mix by inverting and incubate at room temperature for 5 minutes.

12. Pellet the DNA at $13,000 \mathrm{rpm}$ for 10 minutes.

13. Wash the pellet with $70 \%$ ethanol $(90 \mu \mathrm{l})$ at 13,000 rpm for 3 minutes.

14. Dry the pellet and dissolve in $20-25 \mu l$ of $\mathrm{T}_{10} \mathrm{E}_{1}$ or sterile water.

15. Add Rnase at $20 \mathrm{mg} / \mu 1$.

\subsubsection{PCR Amplification}

DNA extracted from leaves of transformants was used as template DNA, Taq DNA polymerase (Bangalore Genei), Taq Buffer (Bangalore Genei), dNTPs (Bangalore Genei), $\mathrm{Mgcl}_{2}$ (Bangalore Genei) and Primers were used for cyclic amplification of DNA. Following CrylAc-CrylEc specific primers were used for confirming transgenic.

Sequence of CrylAc-CrylEc primers:

Forward $5^{1}$ CCAGAGAACGAGATC TTGGAC $3^{1}$

Reverse $3^{1}$ AGTATTGTACCATCTAACAGCGTA $5^{1}$

Sequence of $n p t$-II primers:

Forward $5^{1}$ GAG GCD ATT CGG CTA TGA CTG $3^{1}$

Reverse $3^{1}$ ATC GGG AGG GGC GAT ACC GAT $5^{1}$

The PCR mix was made fresh in bulk depending on the number of samples each time. Each $20 \mu \mathrm{l}$ mix contained:

\begin{tabular}{ll}
\hline Taq polymerase & $0.33 \mu 1$ \\
Taq Buffer & $2.5 \mu 1$ \\
dNTPs & $1 \mu 1$ \\
$\mathrm{MgCl}_{2}$ & $0.5 \mu 1$ \\
Forward primer & $1 \mu 1$ \\
Reverse primer & $1 \mu 1$ \\
Template & $1 \mu 1$ \\
SDDW & $12.67 \mu \mathrm{l}$ \\
Total & $20 \mu \mathrm{l}$ \\
\hline
\end{tabular}

The PCR amplification steps were as follows

\begin{tabular}{lllll}
\hline Stage & Step & $\begin{array}{l}\text { Temperature } \\
\left(\mathbf{C}^{\mathbf{0}}\right)\end{array}$ & $\begin{array}{l}\text { Duration } \\
(\mathbf{m i n})\end{array}$ & $\begin{array}{l}\text { No. of } \\
\text { cycle }\end{array}$ \\
\hline \multirow{2}{*}{ I } & 1. Initial & 94 & 5 & 1 \\
& Denaturation & 94 & 1 & 39 \\
\multirow{2}{*}{ II } & 1. Denaturation & 94 & 1 & \\
& 2. Annealing & 70 & 1 & \\
\multirow{2}{*}{ III } & 3. Extension & 72 & 10 & 1 \\
& 1. Final Extension & 72 & - & - \\
\hline
\end{tabular}

After the completion of required cycles of amplification, the samples were stored at $4{ }^{0} \mathrm{C}$ in a refrigerator until further use. Here, for amplification of plasmid we standardized the protocol by using 6 temperatures $\left(60.6{ }^{\circ} \mathrm{C}\right.$, 62.3 ${ }^{0} \mathrm{C}, 57.2{ }^{0} \mathrm{C}, 56.5{ }^{0} \mathrm{C}, 55.0^{\circ} \mathrm{C}$ and $54.1{ }^{0} \mathrm{C}$ ) to find out which temperature is suitable for amplification.

\subsubsection{Agarose Gel Electrophoresis of DNA}

1. Sufficient $1 \mathrm{x}$ electrophoresis buffer was prepared from $50 \mathrm{x}$ stock.

2. Agarose powder was added (1\%) to TAE buffer (1x) and was dissolved by melting at $100{ }^{0} \mathrm{C}$. The solution was cooled to $50{ }^{\circ} \mathrm{C}$ and ethidium bromide was added $(0.5 \mu \mathrm{g} / \mathrm{ml})$ and the comb was positioned at $0.5-1.0 \mathrm{~mm}$ above the plate. Then agarose solution was poured into the gel frame and was allowed to polymerize. The gel tank was filled with TAE buffer (1x) just enough to cover the surface of the gel to a depth of $1 \mathrm{~mm}$.

3. The DNA sample was mixed with gel loading buffer and it was slowly loaded into the wells of the submerged gel using a disposable microtips. DNA /Eco RI + Hind II double digest were used as molecular weight marker.

4. The system was connected to the power supply and electrophoresis was carried out at 100 volts for 30 $45 \mathrm{~min}$.

5. It was examined by gel documentation system.

\section{Results and Discussion}

Cotton breeding for insect resistance has been limited by a lack of sufficient genetic variation in the existing germplasms. Therefore, genetic engineering provides the possibility of creating varieties carrying new properties coming even from heterologous source (Lycett and Grierson 1990; Dhaliwal et al., 1998). Exogenous pesticidal transgenes can be introduced into plants. Agrobacterium mediated plant transformation offers advantages like reducing copy number of the transgene and little co-suppression (Konez et al., 1994; Hansen et al., 1997).

\subsection{Agrobacterium Strain and Binary vectors}

The disarmed Agrobacterium strain LBA 4402 harbouring binary vector pCAMBIA, carrying CrylAcCrylEc genes linked to the CaMV35S promoter, the nos 
transcription terminator (amplified from $\mathrm{Pb} 101.1$ with $M f e I$ and EcoRI restriction sites at the ends) and $n p t$-II gene under the control of nopaline synthase (nos) promoter and terminator was used in transformation studies. Hygromycin resistance as selection marker. CrylAc-CrylEc genes is to control Helicoverpa armigera and Spodoptera litura.

The Agrobacterium LBA 4402 containing above mentioned genes was maintained on solid Yeast Extract Mannitol Agar (YEM) medium containing kanamycin at 50 $\mathrm{mg} / \mathrm{ml}$ and $25 \mathrm{mg} / \mathrm{ml}$ rifampicin. It was subcultured once in every 30-40 days on fresh medium and incubated at $28{ }^{\circ} \mathrm{C}$ temperature for 48 hours followed by $4-6{ }^{0} \mathrm{C}$ for rest of the period.
A colony of bacteria grown for 48 hours was taken from petridish and was inoculated in $150 \mathrm{ml}$ of liquid YEM medium containing $50 \mathrm{mg} / \mathrm{l}$ of Kanamycin and $25 \mathrm{mg} / \mathrm{l}$ rifampicin and incubated for $45-48$ hours at $22{ }^{0} \mathrm{C}$ under orbital shaker with $150 \mathrm{rpm}$. When bacterium growth reached to OD $(600 \mathrm{~nm})$ of $0.6 \mathrm{~g}$ pellet of bacterium obtained after centrifuge at $8000 \mathrm{rpm}$ for 5 minute. It was resuspended in $150 \mathrm{ml}$ of $\mathrm{MS}$ medium and $150 \mu \mathrm{M}$ of acetosyringone was added to the Agrobacterium culture before 30 minute of its use.

\subsection{Designing and Chemical Synthesis of the Chimeric Cry1 Ac and Cry1EC Genes}

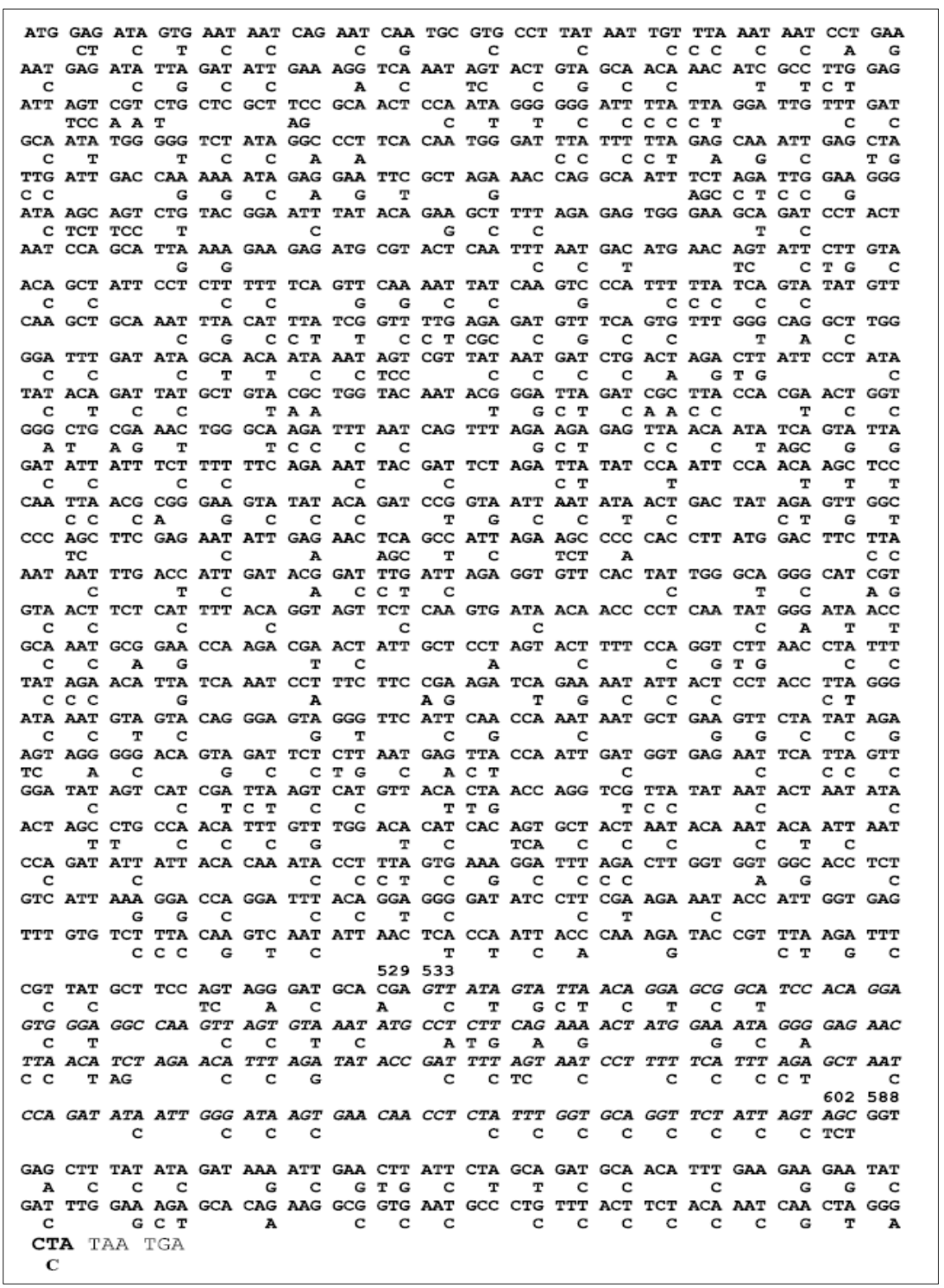

Fig. 3. Designing of the gene coding for chimeric $\delta$-endotoxin CrylEc

A $1.9 \mathrm{kbp}$ double stranded DNA was theoretically designed (Fig. 3) by modifying the sequence of natural CrylEa gene, to encode the chimeric d-endotoxin CrylEC. Plant-preferred translation initiation context (Sawant et al., 2001) and codons were used in designing the gene. The putative transcription termination signals (AAUAAA and its variants), mRNA instability elements (ATTTA) and potential splice sites were eliminated and long hairpin loops were avoided. The whole sequence was synthesised as 58 overlapping oligonucleotides.

The oligonucleotides were synthesised on Gene Assembler Special DNA synthesiser, purified on urea - 
polyacrylamide gel and assembled in four parts (Fig. 4) by assembly polymerase chain reaction (Singh et al., 1996). Eight oligonucleotides were assembled into a BamHI XhoI fragment (340 bp long), 12 into a XhoI - AccI fragment (511 bp long), 24 into a AccI - ApaI fragment (680 bp long) and 14 into a ApaI - EcoRI fragment (519 bp long). These were cloned in pBluescript SK+ cloning vector.

At least four clones were sequenced in each case to locate the errors in synthesis. Sequencing was done on model 373 automatic DNA sequencer using fluorescent dye termination cycle sequencing kit. The errors were corrected by exchanging the regions containing mutations with those from correct clones. Finally, the error-free DNA fragments were stepwise ligated to give about $1.9 \mathrm{kbp}$ full length gene.

CrylAc protein (endotoxin) produced in $B t$ transgenic cotton is effective in controlling Helicoverpa armigera. The CrylAc (1915bp) gene cloned earlier from native $B$. thuringiensis at UAS, Dharwad was considered for modification (Fig. 5) (Kumaraswamy, 2005). The purpose of redesigning CrylAc was to create a synthetic gene that would be expressed at high level in plant cells.

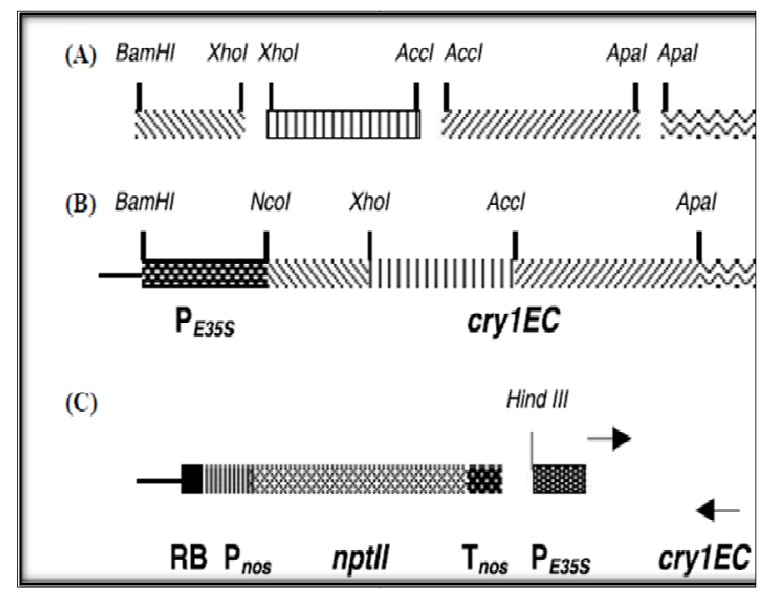

Fig. 4. Construction of CrylEc for plant transformation

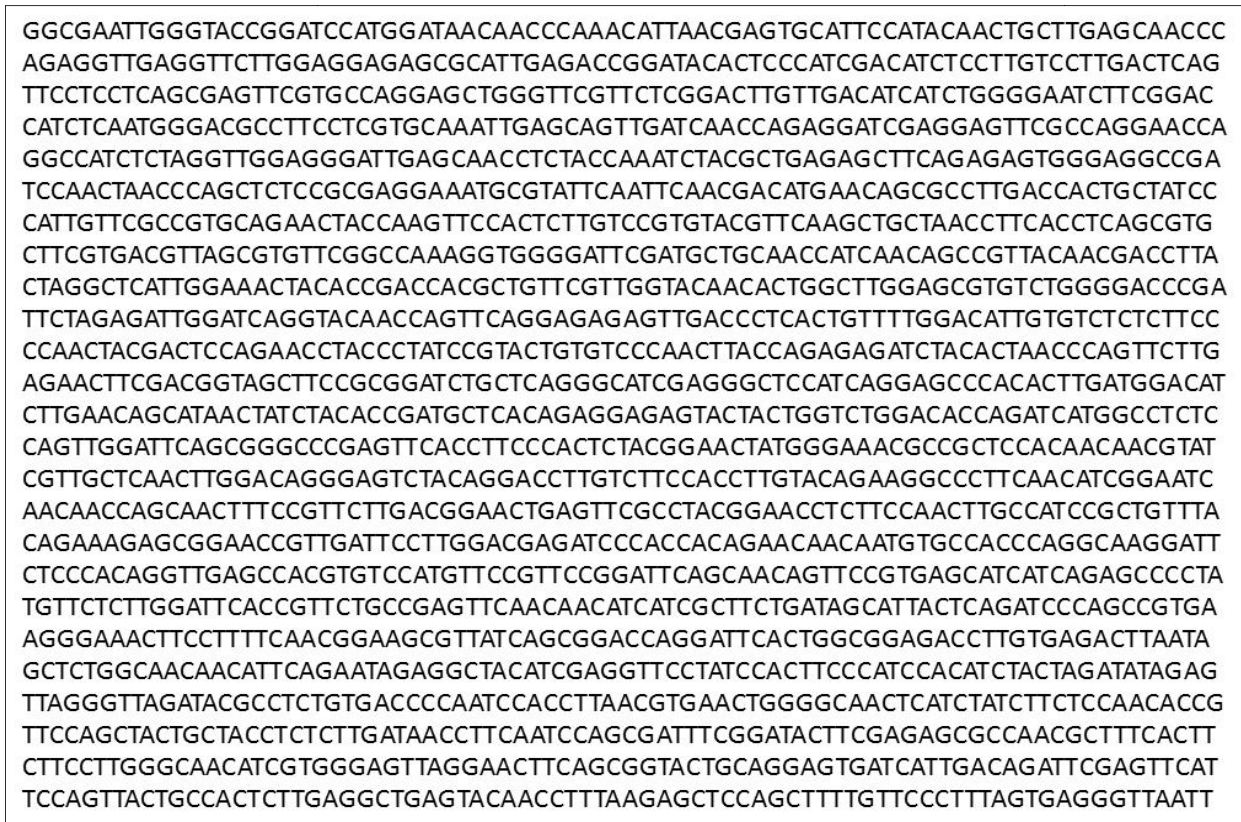

Fig. 5. Gene Sequence of M CrylAc (1915bp)

\subsection{PCR Amplification}

DNA extracted from leaves of transformants was used as template DNA. Taq DNA polymerase, Taq Buffer, dNTPs, Mgcl2 and Primers were used for cyclic amplification of DNA. Following CrylAc-CrylEc specific primers were used for confirming transgenic.

Sequence of CrylAc-CrylEc primers:

Forward $5^{1}$ CCAGAGAACGAGATC TTGGAC $3^{1}$

Reverse $3^{1}$ AGTATTGTACCATCTAACAGCGTA $5^{1}$

Sequence of $n p t$-II primers:

Forward $5^{1}$ GAG GCD ATT CGG CTA TGA CTG $3^{1}$

Reverse $3^{1}$ ATC GGG AGG GGC GAT ACC GAT $5^{1}$

After the completion of required cycles of amplification, the samples were stored at $4{ }^{0} \mathrm{C}$ in a refrigerator until further use. Here, for amplification of plasmid we standardized the protocol by using 6 temperatures $\left(60.6{ }^{\circ} \mathrm{C}\right.$, $62.3{ }^{0} \mathrm{C}, 57.2{ }^{\circ} \mathrm{C}, 56.5{ }^{\circ} \mathrm{C}, 55.0{ }^{\circ} \mathrm{C}$ and $\left.54.1{ }^{0} \mathrm{C}\right)$. The results showed that the plasmid has amplified at four temperatures $\left(57.2{ }^{\circ} \mathrm{C}, 56.5{ }^{\circ} \mathrm{C}, 55.0{ }^{\circ} \mathrm{C}\right.$ and $\left.54.1{ }^{\circ} \mathrm{C}\right)$ (Plate 2).

\subsection{In Planta Genetic Transformation}

Several methods of injuring the plant target tissue for transformation and regeneration were examined in an effort to improve the efficiency of production of transgenic cotton. Agrobacterium tumefaciens strain carrying Cryl AcCrylEc was used for transformation of RCR4 genotype. The effect of wounding on established seedling, effect of vertical cut on well established seedling and regeneration was studied. 
The seedlings in pots were co-cultivated with solid Agrobacterium culture after cutting the meristematic tip with sharp knife. The number of seedlings co-cultivated, number of seedlings established and the number of seedlings showing transformed status are presented in Table 1. PCR was performed to confirm the presence of the transgene in the plants that were selected to be advanced further. The results showed that non of plants had trangenes CrylAc-CrylEc as detected through PCR amplification.

In planta genetic transformation was carried out and the plants were tested in $\mathrm{T}_{0}$ generation by means of PCR amplification for the genes CrylAc-CrylEc. The results obtained were not amplified the CrylAc-CrylEc. Hence the transformation of the genes was not up to mark and the plants of $\mathrm{T}_{1}$ generation are also not confirmed.

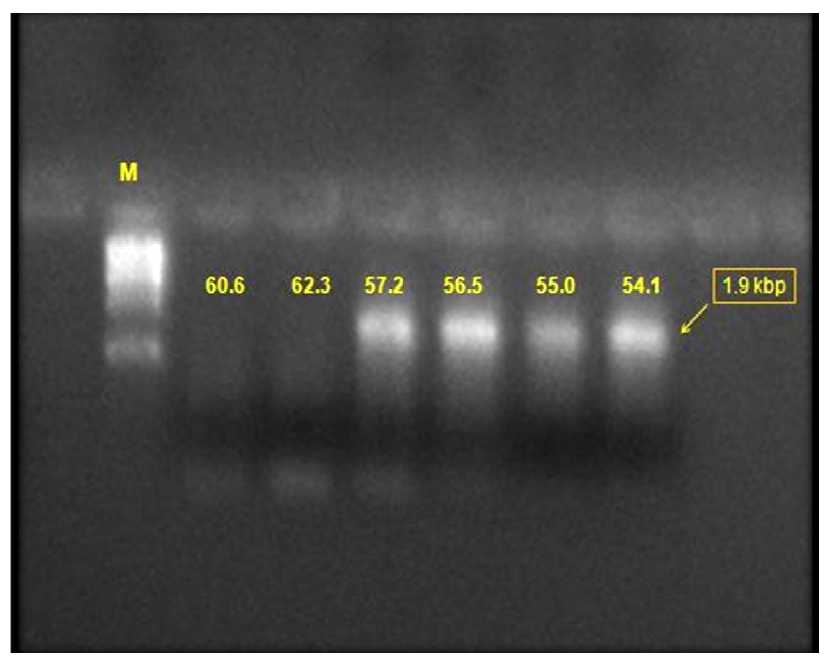

Plate 2. Plasmid amplification at four temperature

Table 1. Number of cotton seedlings co-cultivated, established and transformed in planta genetic transformation study

\begin{tabular}{llllll}
\hline Genotype & Group & Total number of seedlings & Number of seedlings co-culivated & $\begin{array}{l}\text { Number of plants } \\
\text { established }\end{array}$ & Number of plants transformed \\
\hline RCR4 & Group 1 & 100 & 92 & 81 & Nil \\
& Group 2 & 111 & 97 & 88 & Nil \\
& Group 3 & 117 & 87 & 75 & Nil \\
& Group 4 & 90 & 77 & 62 & Nil \\
Total & & 418 & 353 & 306 & Nil \\
\hline
\end{tabular}

\section{Discussion}

Genetic engineering offers a directed method of plant breeding that selectively targets one or a few traits for introduction into the crop plant. The first transgenic cotton plants were obtained in 1987 (Umbeck et al., 1987). The deployment of endotoxins for the protection of crops against insect pests requires the availability of proteins that cause high toxicity to target pests at low level of expression. It is also important to develop novel toxins that bind to different receptors and can therefore be valuable in pyramiding for durable pest resistant. Since crops are damaged by a variety of herbivores, it is desirable to identify endotoxins that can cause mortality or growth inhibition of different target pest species. In this respect, the development of $C r y 1 E c$ in this work is important since both Spodoptera and Helicoverpa are common agricultural pests and serious bollworms of cotton. Several proteins, especially $C r y l A c$ cause very high toxicity to Helicoverpa sp. Other proteins with satisfactory activity against Helicoverpa are CrylAb, Cry $1 \mathrm{Ia}_{5}$, Cry $2 \mathrm{Ab} 2$ etc. (Chambers et al., 1991; von Tersch et al., 1991; Lambert et al., 1996; Selvapandiyan et al., 1998; Perlak et al., 2001). The CrylC has been reported to show significant toxicity to Spodoptera sp. (Hone'e et al., 1988; Hofte and Whiteley, 1989; Gill et al., 1992; Kalman et al., 1993) at reasonably low level in larval diet. Within the subgroup of Cryl $d$ endotoxins, a few other proteins that resemble CrylC (Visser et al., 1990; Kalman et al., 1993) and CrylF (Chambers et al., 1991) have been reported to show toxicity to Spodoptera sp., though at relatively higher $\mathrm{LC}_{50}$ values. The CrylE resembles the CrylC subgroup to the extent of about $70 \%$. It does not cause significant toxicity to S. exigua (Visser et al., 1990; Masson et al., 1992; Bosch et al., 1994) but appears to bind to receptors different from CrylC. Therefore, modification of CrylE and search for proteins with high toxicity to Spodoptera sp. have been objectives in several earlier studies.

Recent advances in transgenic technology now make it possible to transfer and express various genes in agriculturally important species like cotton. The rapid development of cotton transformation technology not only provides a valuable method for introducing useful genes into cotton to improve important agronomic traits, but also helps in the study of gene function and regulation. Although transformation rates have been significantly improved since the first report of success in the transformation of cotton (Firoozabady et al., 1987; Umbeck et al., 1987), increase in transformation efficiency is still needed.

Transformation techniques that evade tissue culture (Graves and Goldman, 1986) therefore become important in recalcitrant crops such as cotton. In the present study, in planta transformation protocol was used to develop transformants (Rohini and Sankara Rao, 2000a; Rohini and Sankara Rao, 2000b; Rohini and Sankara Rao, 2001). In this method, the seedling shoot is embedded in the stem between the cotyledons, break off one cotyledons to expose shoot apex and cut the tissue in the shoot apex to make wound and Agrobacterium is targeted to the wound. Therefore, Agrobacterium tumefaciens transfers the gene into the genome of diverse cells which are already destined to develop into specific organs and the meristematic cells 
still to be differentiated. This results in the primary transformants $\left(\mathrm{T}_{0}\right)$ being chimeric in nature. This is the reason for the analysis of the transgenic plants to be carried out in the $\mathrm{T}_{1}$ generation.

In in planta method of transformation, invariably the transformation of a few cell/cells happen and such cell/cells of targetted tissue (like shoot apical) will become part of the regenerated shoot where in the transformed cells prevail as chimeric. These plants/ shoots are refered as primary transformed and such transformed chimeric becomes flowers and seeds are harvested, they will have whole germ transformed status. In the present study the tissue choosen for transformation status was basically chimeric / mosaic in related for transformation status and it would be likely that a non- transformed tissue resulted in no PCR amplified with gene specific primers.

\section{Future Line of Work}

In planta genetic transformation needs to be tested by refining the protocol meant for cotton.

\section{Acknowledgement}

The support received from NMITLI project funded by CSIR is gratefully acknowledged.

\section{References}

[1] Aslam, M., Hrzog, C. A. and Chalfant, R. B., 2000, Different cotton strains screened for resistance to Heliothis spp. (Lepidoptera : Noctuidae) in the field. Pak. J. Biol. Sci., 3 (8) : 1290-1291.

[2] Bevan, M., Barnes, W. M. and Chilton, M. D., 1983a, Structures and transcription of nopaline synthase gene region of T-DNA. Nucleic Acids Res., 11 : 369-385.

[3] Bosch, D., Schipper, B., Van Der Klei, H., De Maagd, R. A. And Stiekema, W. J., 1994, Recombinant Bacillus thuringiensis crystal proteins with new properties : possibilities for resistance management. Bio/Tech., 12 : 915918.

[4] Broer, I., Droge-Laser, W., Barkers, R. F., Neumann, K., Klipper, W. and Puhler., 1995, Identification of Agrobacterium tumefaciens C58 T-DNA genes c and f and their impact on crown gall tumor formation. Plant Mol. Biol., $27: 41-57$.

[5] Chambers, J. A., Jelen, A., Gilbert, M. P., Jany, C. S., Johnson, T. B. and Gawron-Burke, C., 1991, Isolation and characterization of a novel insecticidal crystal protein gene from Bacillus thuringiensis subsp. aizawai. J Bacteriol., $173: 3966-3976$.

[6] Dhaliwal, H. S., Kawai, M. and Uchimiya, H., 1998. Genetic engineering for abiotic stress tolerance in plants. Plant Biotech., 15 : 1-10.

[7] Enriquez-Obregon, G. A., Vazquez-Padron, R. I., Prietsosansonov, D. L., Delariva, G. A. and Selman-Housein, G., 1998, Herbicide resistant sugarcane (Saccharum officinarum L.) plants by Agrobacterium mediated transformation. Planta., $6: 20-27$.

[8] Firoozabady, E., Deboer, D. L., Merlo, D. J., Halk, E. L., Amerson, L. N., Rashka, A. E. and Murray, E. E., 1987, Transformation of cotton (Gossypium hirsutum L.) by Agrobacterium tumefaciens and regeneration of transgenic plants. Plant Mol. Biol., 10 : 105-116.

[9] Gill, S. S., Cowles, E. A. and Pietrantonio, P. V., 1992, The mode of action of Bacillus thuringiensis endotoxins. Ann Rev Entomol., 37 : 615-636.

[10] Graves, A. C. F., and S. L. Goldman, 1986. The transformation of Zea mays seedlings with Agrobacterium tumefaciens, Plant Mol. Biol., 7 : 43-50.

[11] Hansen, G., Shillito, R. D. and Chilton, M. D., 1997, Tstrand integration in maize protoplants after co delivery of a T-DNA substrate and virulence genes. Proc. of the Nation. Acad. of Sci. of USA., 94 : 11726-11730.

[12] Herrnstadf, C., Soanres, G. G., Wilcox, E. R. and Edward, D. L., 1986, A new strain of Bacillus thuringiensis with activity against coleopteran insects. Biotech., $4: 305-308$.

[13] Hoftey, H. and Whiteley, H. R., 1989, Insecticidal crystal protein of Bacillus thuringiensis. Microbiol Rev., 53 : 242255.

[14] Hone'e, G., Van Der Salm, T, and Visser, B., 1988, Nucleotide sequence of crystal protein gene isolated from B. thuringiensis subspecies entomocidus 60. 5 coding for a toxin highly active against. Spodoptera species Nucleic Acids Res., $16: 6240$.

[15] Kalman, S., Kiehne, K. L., Libs, J. L. and Yamamoto, T., 1993, Cloning of a novel cryIC-type gene from a strain of Bacillus thuringiensis subsp. galleriae. Appl Environ Microbiol., 59 : 1131-1137.

[16] Katageri, I. S., Vamadevaiah, H. M., Udikeri, S. S., Khadi, B. M. and Kumar, P. A., 2007, Genetic transformation of an elite Indian genotype of cotton (Gossypium hirsutum L.) for insect resistance. Current Sci., 93 (12) : 1843-1847.

[17] Konez, C., Nemeth, K., Redei, G. P. and Scel, J., 1994, Homologous recombination and gene silencing in plants. Plant Cell Rep., 22 : 167-174.

[18] Krattiger, K. and Anatole, F., 1997, Insect resistance in crops : a case study of Bacillus thuringiensis $(B t)$ and its transfer to developing countries. ISAAA Briefs. pp. 42.

[19] Krieg, A., Huger, A., Langenbuch, G. and Schneter, W., 1983, Bacillus thuringiensis var. tenebrionis : a new pathoype effective against larvae of Coleoptera. J. Appl. Entomol., 96 : 500-508.

[20] Kumaraswamy, G. K, 2005, Expression of cry1Ac from native Bacillus thuringiensis D1 in Escherichia coli, M. Sc. (Agri) Thesis, Univ. Agricl. Sci., Dharwad.

[21] Lambert, B., Buysse, L., Decock, C., Jansens, S., Piens, C. and Saey, B., 1996, A Bacillus thuringiensis insecticidal crystal protein with a high activity against members of the family noctuidae. Appl Environ Microbiol., 62 : 80-86.

[22] Lycett, G. W. and Grierson, D., 1990. Genetic engineering of crop plants. Butter worth, London. 
[23] Lyer, V. N., Klee, H. J. and Nester, E. W., 1982, Units of genetic expression in the virulence region of a plant tumor inducing plasmid of Agrobacterium tumefaciens. Mol. Gen. Genet., $188: 418-424$.

[24] Maizer, M., Pannetie, C., Tourneur, J., Jouanin, L. and Giband, M., 1997, Expression of Bt toxin genes in plant cells. Biotech. Annu. Rev., $3: 313-347$.

[25] Masson, L., Moar, W. J., Van Frankenhuyzen, K., Bosse, M. and Brousseau, R., 1992, Insecticidal properties of a Crystal protein gene product isolated from Bacillus thuringiensis subsp. kenyae. Appl Environ Microbiol., 58 (2) : 642-646.

[26] Perlak, F. J., Oppenhuizen, M., Gustafson, K., Voth, R., Sivasupramaniam, S. and Heering, D., 2001, Development and commercial use of Bollgard cotton in the USA - early promises versus today's reality. Plant J., 27 : 489-501.

[27] Rohini, V. K., and K. Sankara Rao, 2001. Transformation of peanut (Arachis hypogaea L.) with tobacco chitinase gene : variable response of transformants to leaf spot disease, Plant Sci., 160 (5) : 883-892.

[28] Rohini, V. K. and K. Sankara Rao, 2000a. Transformation of peanut (Arachis hypogeae L.) : a non-tissue culture based approach for generating transgenic plants, Plant Sci., 150 : 41-49.

[29] Rohini, V. K., and K. Sankara Rao, 2000b. Embryo transformation, a practical approach for realizing transgenic plants of safflower (Carthamus tinctorius L.), Ann. Bot. 86 : 1043-1049.
[30] Sawant, S. V., Kiran, K., Singh, P. K. and Tuli, R., 2001, Sequence architecture downstream of the initiator codon enhances gene expression and protein stability in plants. Plant Physiol., 126 : 1630-1636.

[31] Selvapandiyan, A., Reddy, V. S., Kumar, P. A., Tewari, K. K. and Bhatnagar, R. K., 1998, Transformation of Nicotiana tabacum with a native crylla5 gene confers complete protection against Heliothis armigera. Molec. Breed., 4 : 473-478.

[32] Singh, R. K. and Chaudhary, B. D., 1996, Biometrical methods in quantitative genetic analysis. Kalyani publishers, Ludhiana, pp. 191-200.

[33] Stachel, S. E. and Nester, E. W., 1986, The genetic and transcriptional organization of the vir region of the A6T plasmid of Agrobacterium tumefaciens. Embo. J., 4 : 891898.

[34] Umbeck, P., Johnson, G., Barton, K. and Swain, W., 1987, Genetically transformed cotton (Gossypium hirsutum L.) plants. Bio/Tech., 5 : 263-266.

[35] Visser, B., Munsterman, E., Stoker, A. and Dirkse, W. G., 1990, A novel Bacillus thuringiensis gene encoding a Spodoptera exigua - specific crystal protein. $J$ Bacteriol., $172: 6783-6788$.

[36] Von Tersch, M. A., Robbins, H. L., Jany, C. S. and Johnson, T. B., 1991, Insecticidal toxins from Bacillus thuringiensis subsp. kenyae : gene cloning and characterization and comparison with B. thuringiensis subsp. kurstaki CryIAI toxins. Appl Environ Microbiol., 57 : 349-358. 